\title{
免疫チェックポイント阻害薬再導入における安全性の検討
}

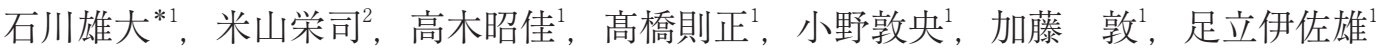 \\ 富山大学附属病院薬剂部 ${ }^{1}$, 黑部市民病院薬剂科 ${ }^{2}$
}

\section{Safety Evaluation of Retreatment with Immune Checkpoint Inhibitors}

\author{
Yudai Ishikawa* ${ }^{* 1}$ Eiji Yoneyama ${ }^{2}$, Akiyoshi Takaki ${ }^{1}$, Norimasa Takahashi ${ }^{1}$, \\ Atsuo Ono ${ }^{1}$, Atsushi Kato ${ }^{1}$ and Isao Adachi ${ }^{1}$ \\ Department of Pharmacy, Toyama University Hospital ${ }^{1}$, Department of Pharmacy, Kurobe City Hospital ${ }^{2}$
}

$\left[\begin{array}{l}\text { Received August 3, } 2019 \\ \text { Accepted October 2, } 2019\end{array}\right]$

\begin{abstract}
Immune checkpoint inhibitors (ICIs) play an important role in oncology, as they generate novel toxicities known as immune-related adverse events (irAE) which affect multiple organ systems. Since irAEs have been reported to have potential clinical benefits for patients, retreatment using ICIs following recovery from irAEs is sometimes attempted, though there are limited data about the safety of using this strategy on patients with a serious irAE history. Here, the safety of retreatment after irAE across patients with different cancer types was evaluated. Fifty-three patients experienced treatment interruption because of irAEs; of these, 31 patients were then retreated with ICIs. Endocrine disorder as the initial irAE was observed more often in patients who were retreated; conversely, pneumonitis was observed more often in patients who were not retreated with ICIs. Manageable flare-up or novel irAEs occurred in 19 patients, while irAEs did not occur after retreatment in 12 patients. The number of days from the beginning of ICI treatment to the first irAE (within 100 days) as well as patient gender were found to be risk factors that were significantly related to relapses or new onsets of irAE. In 19 patients who experienced flare-up or new irAEs, the secondary irAE grade increase did not differ significantly compared to that of the initial irAE. The results of this study are important in helping to evaluate the risk of retreating patients with ICIs.
\end{abstract}

Key words — immune checkpoint inhibitors, immune-related adverse events, oncology, immunology

\section{緒言}

近年, cytotoxic T lymphocyte antigen 4 (CTLA-4), programmed death 1 (PD-1), PD ligand 1 (PD-L1) を標的とする多くの免疫チェックポイント阻害薬 (immune checkpoint inhibitors: ICIs)の開発により,

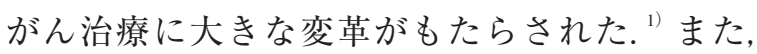
ICIs は悪性黒色腫, 非小細胞肺がん, 腎細胞がん, 胃がん，頭頸部がん，ホジキンリンパ腫といった 様々ながん腫において化学療法を上回る生存期間 の延長が確認され，進行がんの標準治療となりつ つある. ${ }^{2)}$ 同時に ICIs 使用時は免疫関連有害事象 （immune-related adverse events: irAE）に注意が必 要である。irAEとは皮虐, 肺, 消化管, 肝臓, 内 分泌器官など様々な臟器に生じる自己免疫疾患様 の障害で, ${ }^{3)}$ 抗 PD-1 抗体では約 70\%に出現し, ${ }^{4}$ 抗 CTLA-4 抗体では約 90\%にまでも達する. ${ }^{5)}$ irAE 発生時はステロイドを中心とした免疫抑制剂が使 用されるが, ${ }^{6}$ 重症化すれば致死的になる場合も あるので ICIs 自体の適切な中止や休薬が必要で ある. ${ }^{7}$ 一方, 出現した irAEの Grade が高いと, 疾 患の予後が良好であるとの報告もあることから, ${ }^{8}$ さらなる治療効果を狙って臨床現場では irAE 発症 後に ICIs の再導入が試みられる場合がある。し

\footnotetext{
*テ930-0194＼cjkstart富山市杉谷2630
} 
かし，海外のガイドラインには再導入の目安が記 載されているものの, ${ }^{9}$ 国内外を通しても実臨床 に扔ける安全性の報告は, 疾患限定的な調查や使 用薬剮限定的な調查が少数あるのみであり, ${ }^{10-12}$ 同じあるいは異なる ICIs の再導入に関する安全性 は未確立である. ${ }^{13)}$ さらに，抗 PD-1 抗体であるぺ ムブロリズマブの microsatellite instability (MSI)-high 固形がんへの適応拡大によって, irAE マネジメ ントはより臟器や疾患に対して普遍的に望まれて いる。このような背景のなか, 我々は今回, irAE 発症後の ICIs 再導入に押ける安全性に関して, 臓 器疾患横断的, 薬剂横断的に調査を行ったので報 告する.

\section{方 法}

\section{1. 対象}

2014 年 1 月 1 日〜 2019 年 2 月 28 日の間で, 富 山大学附属病院において, ICIs（イピリムマブ, ニボルマブ, ペムブロリズマブ, アテゾリズマブ, デュルバルマブ）の単剤あるいは併用治療を受け た患者のうち，治療を 1 週間以上延期しなければ ならない irAE が発生した患者を対象とした。な お，殺細胞性抗がん薬との併用症例は除外した。 $\operatorname{irAE}$ の判断, irAE 発生時の各薬殽の中止および 再導入に関しては, 各薬剤の添付文書, 適正使用 ガイド，ガイドライン等に準じて主治医が判断し た。 また, 再導入群の全症例で再導入された ICIs は初回投与された薬片と同じであった。

\section{2. 調查方法}

電子カルテを用いて後方視的調査を行った.なお， irAEの重症度については, Common terminology criteria for adverse events version 4.0 (CTCAE ver.4) を用いて評価した。

\section{3. 統計}

有意性の検討において，データの正規性は $\chi^{2}$ 適合度検定によって評価した。データが正規分布 に従わず，独立した 2 群間の差の検定を行う場合 は，Mann-Whitneyの $U$ 検定を用いて調べた．正 規分布に従う際，2 群間に関連がない場合の連続
変数に関して, 等分散とみなせる場合は Student の $t$ 検定を, みなせない場合は Welch の検定を用 いて調べた．また，2 群間に関連がある場合の順 序変数に関する有意性はウィルコクソン符号付順 位検定を用いて調べた。ささらに，2要因の比較に は, Fisher の正確確率検定あるいは $\chi^{2}$ 独立性の 検定を使用し, $P<0.05$ の場合, 統計学的有意差 ありとした。なお，統計解析には, Statcel 4 （(有) オーエムエス出版, 東京）を用いた。

\section{4. 倫理的配慮}

本研究は「人を対象とする医学系研究に関する 倫理指針」を遵守し, 当院の倫理審査委員会の承 認（臨 28-138）を得て実施した。

\section{結 果}

\section{1. 患者背景}

irAEにより，投与が 1 週間以上延期された患 者は 53 名であった，そのうち, ICIs が永続的に 投与中止となった患者は 22 名 (非再導入群), 再 導入された患者は 31 名であった (再導入群)。両 群の患者背景を表 1 に示す。なお, 調查対象期 間内にデュルバルマブ使用患者に関しては，治療 中断となった該当症例がいなかったため, 表 1 に は記載していない. 統計的には非再導入群は再導 入群に比べ, 65 歳より高齢の患者が有意に多く $(P$ $<0.05)$, 初回に発生した irAE の Grade も有意に 高かった $(P<0.001)$. 同時に, 非再導入群では, irAE 発生時に経口あるいは静注ステロイドによ る治療を有した患者が多かった $(P<0.001)$. irAE の種類も ICIs 再導入に影響を及ぼす因子であり $(P<0.05)$, 非再導入群では肺臓炎が, 再導入群 では内分泌障害が多かった。

\section{ICI 再導入の安全性}

投与中断を要する irAEが生じた後, ICIs を再 導入した際の irAEの出現状況を図 1 に示す。約 9.7\%の患者は初回の irAE が再燃し, 約 51.6\%の 患者は新規の irAEを発症した（再燃/新規発症 群).一方, 約 $38.7 \%$ の患者は irAE が生じること なく, 再導入後経過した (無症状群), irAEが再 
表 1 患者背景（非再導入群と再導入群）

\begin{tabular}{|c|c|c|c|}
\hline 調査項目 & 非再導入群 $(\mathrm{n}=22)$ & 再導入群（n=31） & $P$ \\
\hline 年齢中央値（歳）（最小值 - 最大値） & $70.5(45-83)$ & $64(38-85)$ & $0.06^{\mathrm{a})}$ \\
\hline 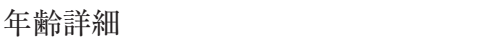 & & & $<0.05^{\mathrm{b})}$ \\
\hline$\leqq 65$ & 5 & 16 & \\
\hline$>65$ & 17 & 15 & \\
\hline 性別（男性 / 女性） & $20 / 2$ & $22 / 9$ & $0.08^{\mathrm{c})}$ \\
\hline Performance Status（0１/2 以上） & $18 / 4$ & $24 / 7$ & $0.49^{\mathrm{c})}$ \\
\hline 治療ライン（1st/2nd 以降） & $3 / 19$ & $8 / 23$ & $0.23^{\mathrm{c})}$ \\
\hline 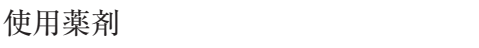 & & & $0.74^{\mathrm{b})}$ \\
\hline ニボルマブ & 16 & 19 & \\
\hline ペムブロリズマブ & 5 & 9 & \\
\hline アテゾリズマブ & 1 & 2 & \\
\hline ニボルマブ + イピリムマブ & 0 & 1 & \\
\hline 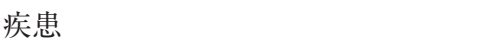 & & & $0.28^{\mathrm{b})}$ \\
\hline 頭頸部がん & 3 & 5 & \\
\hline 非小細胞肺がん & 13 & 14 & \\
\hline 悪性胸膜中脾腫 & 1 & 0 & \\
\hline 胃がん & 2 & 0 & \\
\hline 腎細胞がん & 2 & 4 & \\
\hline 尿路上皮がん & 0 & 2 & \\
\hline 悪性黒色腫 & 1 & 5 & \\
\hline ホジキンリンパ腫 & 0 & 1 & \\
\hline 初回 irAE の Grade & & & $<0.001^{\mathrm{b})}$ \\
\hline Grade 1 and 2 & 5 & 26 & \\
\hline Grade $\geqq 3$ & 17 & 5 & \\
\hline 初回 irAE 発生までの日数（日） & & & $0.79^{c)}$ \\
\hline$\leqq 100$ & 15 & 23 & \\
\hline$>100$ & 7 & 8 & \\
\hline irAE の種類 & & & $<0.05^{\mathrm{b})}$ \\
\hline infusion reaction & 0 & 1 & \\
\hline 肺臓炎 ～～～～～～～～～年 & 11 & 1 & \\
\hline 肝障害 & 2 & 3 & \\
\hline 筋炎 & 1 & 5 & \\
\hline 神経障害 & 2 & 1 & \\
\hline 関節炎 & 2 & 1 & \\
\hline 皮膚障害 & 4 & 6 & \\
\hline 内分泌障害 & 2 & 8 & \\
\hline 下痢 & 0 & 1 & \\
\hline 髄膜炎 & 1 & 0 & \\
\hline その他 ～～～～～～～ & 1 & 5 & \\
\hline 経口または静注ステロイド使用 & 17 & 7 & $<0.001^{\mathrm{b})}$ \\
\hline
\end{tabular}

a）Student の $t$ 検定， b ） $\chi^{2}$ 独立性の検定， c） Fisher の正確確率検定. irAE: immune-related adverse events.

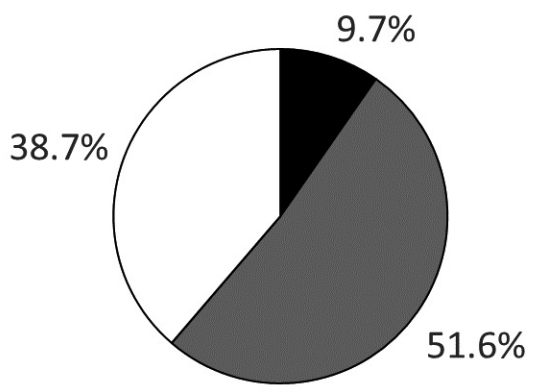

図 1 ICI 再導入時の irAE 発現状況

再燃， $\square$ 新規発症， $\square$ 無症状. ICI: immune checkpoint inhibitor, irAE: immune-related adverse events.
燃㧍よび新規発症した患者の irAE 分類とその Grade 㧍よび転帰を表 2 に示す。再燃/新規発症 群で約 $58 \%$ と半数以上が, 2 回目の irAE 後も ICIs を継続できていたＩCIs を継続できなかった 症例は，irAEによる中止ではなく，腫瘍増悪に よる best supportive care（BSC）への移行であり， ICIs 休薬中の症例も irAE は Grade 2 以下に回復 している. 死亡症例もなかった。 さらに初回 irAE と再燃あるいは新規発症したirAEの Grade の経時的変化を図 2 に示すが， ウィルコクソン 符号付順位和検定にて, ICIs を再導入し, さらな 
表 2 ICIs 再導入による irAE 出現状況と転帰

\begin{tabular}{|c|c|c|c|c|c|}
\hline 症例番号 & 初回 irAE & Grade & 再燃 / 新規 irAE & Grade & 転帰 \\
\hline 1 & 皮膚障害 & 2 & 肺臓炎 & 3 & BSC \\
\hline 2 & 皮膚障害 & 2 & CK 上昇 & 2 & ICIs 継続 \\
\hline (3) & 皮膚障害 & 2 & 皮膚障害 & 3 & ICIs 継続 \\
\hline 4 & 皮膚障害 & 2 & 口腔粘膜炎 & 2 & ICIs 継続 \\
\hline (5) & 肺蔵炎 & 1 & 肺臓炎 & 1 & 経過観察 \\
\hline 6 & 内分泌障害 & 2 & 神経障害 & 3 & BSC \\
\hline 7 & 内分泌障害 & 2 & QT 延長 & 1 & ICIs 継続 \\
\hline 8 & 内分泌障害 & 2 & 下痢 & 2 & ICIs 継続 \\
\hline (9) & 内分泌障害 & 2 & 内分泌障害 & 3 & 経過観察 \\
\hline 10 & 内分泌障害 & 2 & 皮膚障害 & 2 & ICIs 継続 \\
\hline 11 & 神経障害 & 3 & CK 上昇 & 1 & ICIs 継続 \\
\hline 12 & 血栓塞栓症 & 3 & 大腸炎 & 2 & irAE 治療中 \\
\hline 13 & 筋炎 & 1 & $\mathrm{CK}$ 上昇 & 1 & ICIs 継続 \\
\hline 14 & 筋炎 & 2 & 高血糖 & 3 & ICIs 継続 \\
\hline 15 & 筋炎, 肝機能障害 & 2 & 内分泌障害 & 2 & BSC \\
\hline 16 & 肝機能障害 & 3 & 肺臓炎 & 3 & BSC \\
\hline 17 & 肝機能障害 & 2 & 内分泌障害 & 2 & BSC \\
\hline 18 & infusion reaction & 3 & 皮膚障害, 高 AMY 血症 & 3 & ICIs 継続 \\
\hline 19 & CRP 上昇 & 2 & 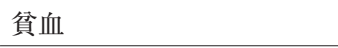 & 3 & ICIs 継続 \\
\hline
\end{tabular}

な拐，番号が○囲みの症例は，初回 irAE と 2 回目に発症したirAEが同じであった再燃患者を示す。また，転帰は 本研究対象期間終了である 2019 年 2 月 28 日時点. ICIs: immune checkpoint inhibitors, irAE: immune-related adversed events, CK: creatine phosphokinase, AMY: amylase, CRP: C-reactive protein, BSC: best supportive care.

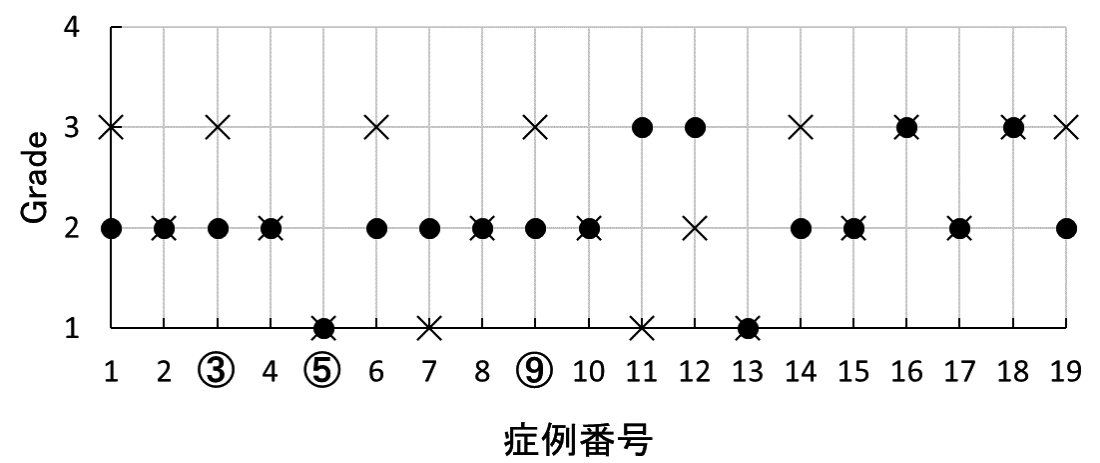

図 2 初回 $\mathrm{irAE}$ と再燃/新規 irAE の Grade の経時的変化

初回 irAE, $\times$ 再燃 $/$ 新規 irAE. 投与前 Grade vs 投与後 Grade. $P=0.56$ (ウィルコクソン符号付順位和検定). なお，横軸でO囲みの症例は，初回 irAE と 2 回目に発症した irAE が同じであった再燃患者を示す.

る irAE が生じた際，その Grade は再燃/新規発 症群において初回 irAEに比べて有意に上昇しな かった（ $P=0.56 ）$

\section{ICI 再導入における irAE 再燃あるいは新規 発症のリスク因子}

再導入群のうち, 無症状群と再燃 / 新規発症群 の患者背景を表 3 に示す。なお，デュルバルマブ 使用患者に関しては，該当症例がいなかったため， 表 3 には記載していない。表 3 より，年齢や治療 ライン，使用薬荗，および疾患に関して，また，
irAEの治療関連としては, 初回 irAE 発生時のス テロイド使用の有無や, 初回 irAE 発生から ICIs 再導入までの期間も, irAE 再燃 / 新規発症と関与が 認められなかった。一方， 2 要因の比較において, 初回 irAE 発生までの日数㧍よび性別が ICIs 再導 入時の $\mathrm{irAE}$ 再燃 / 新規発症と統計学的に有意な関 係があった。

さらに, 再燃 / 新規発症群は無症状群に比べ, ICIs 導入から初回 irAE 発生までの期間が有意に 早かった $(P<0.05)$ (図 3A)。具体的には再燃/ 新規発症群は無症状群に比べ, ICIs 導入から初回 
表 3 患者背景（無症状群と再燃/新規発症群）

\begin{tabular}{|c|c|c|c|}
\hline 調査項目 & 無症状群（n=12） & 再燃 / 新規発症群 $(n=19)$ & $P$ \\
\hline 年齢中央值（歳）（最小值 - 最大値） & $59.5(43-76)$ & $67(38-85)$ & $0.10^{\mathrm{a})}$ \\
\hline 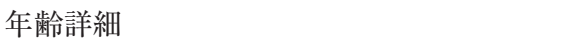 & & & $0.23^{\mathrm{b})}$ \\
\hline$\leqq 65$ & 8 & 8 & \\
\hline$>65$ & 4 & 11 & \\
\hline 性別（男性 / 女性） & $11 / 1$ & $11 / 8$ & $<0.05^{\mathrm{c})}$ \\
\hline Performance Status（0１/2 以上） & $10 / 2$ & $14 / 5$ & $0.43^{\mathrm{c})}$ \\
\hline 治療ライン（1st/2nd 以降） & $1 / 11$ & $7 / 12$ & $0.08^{c)}$ \\
\hline 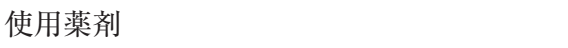 & & & $0.82^{\mathrm{b})}$ \\
\hline ニボルマブ & 8 & 11 & \\
\hline ペムブロリズマブ & 3 & 6 & \\
\hline アテゾリズマブ & 1 & 1 & \\
\hline ニボルマブ + イピリムマブ & 0 & 1 & \\
\hline 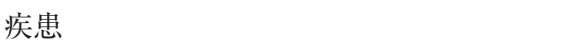 & & & $0.32^{\mathrm{b})}$ \\
\hline 頭頸部がん & 2 & 3 & \\
\hline 非小細胞肺がん & 5 & 9 & \\
\hline 腎細胞がん & 3 & 1 & \\
\hline 尿路上皮がん & 0 & 2 & \\
\hline 悪性黒色腫 ～～～～～～～～～～ & 1 & 4 & \\
\hline ホジキンリンパ腫 & 1 & 0 & \\
\hline 初回 irAE の Grade & & & $0.34^{\mathrm{c})}$ \\
\hline Grade 1 and 2 & 11 & 15 & \\
\hline Grade $\geqq 3$ & 1 & 4 & \\
\hline 初回 irAE 発生までの日数（日） & & & $<0.05^{\mathrm{c})}$ \\
\hline$\leqq 100$ & 6 & 17 & \\
\hline$>100$ & 6 & 2 & \\
\hline 初回 irAE 発生時のステロイド使用 & & & \\
\hline あり/なし & $3 / 9$ & $4 / 15$ & $0.56^{\mathrm{c})}$ \\
\hline 初回 irAE 発生から ICIs 再導入までの期間 & & & \\
\hline （日）中央值（最小值 - 最大值） & $42(21-129)$ & $42(20-364)$ & $0.54^{\mathrm{d})}$ \\
\hline
\end{tabular}

a) Student の $t$ 検定, b ) $\chi^{2}$ 独立性の検定, c） Fisher の正確確率検定, d) Mann-Whitney の $U$ 検定. irAE: immune-related adverse events, ICIs: Immune checkpoint inhibitors.

A

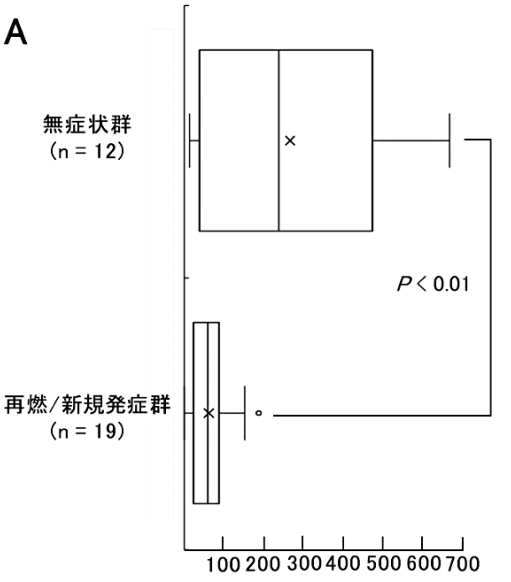

ICIs 導入から初回irAE発生までの日数(日)

\section{B}

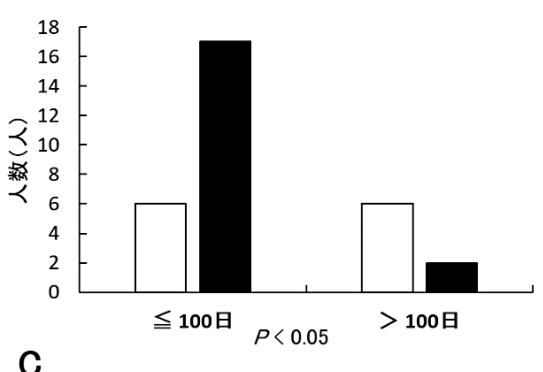

C
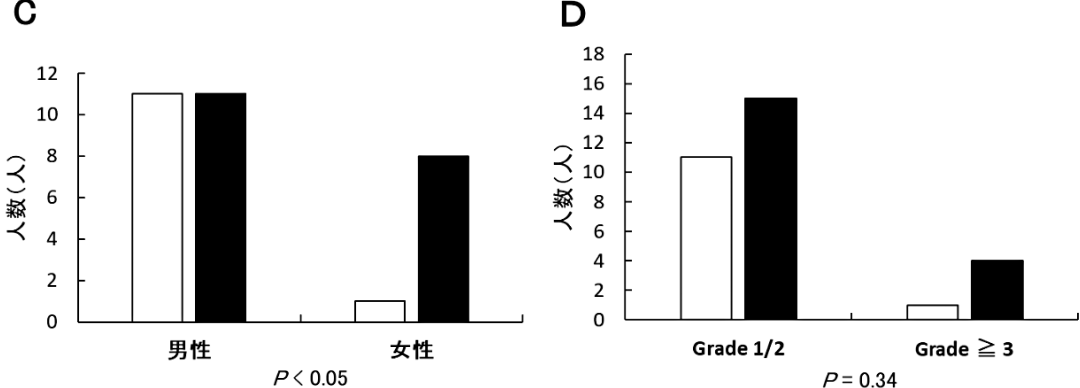

図 3 無症状群と再燃 / 新規発症群の比較

A：ICIs 導入から初回 irAE 発生までの日数比較 各箱ひげ図のラインは左から, 最小值, 第一四分位数, 中央值, 第三四分位数, 最 大值を順に示す. ×は各群の平均值を示しており, ○は外れ值である. ICIs: immune checkpoint inhibitors, irAE: immune-related adverse events Welch の検定 B：ICIs 導入から初回 irAE 発生までの日数を 100 日で区切った場合の人数比較 $\square$ 無症状群, 口再燃/新規発 症群 Fisherの正確確率検定 C : 男女における ICIs 再導入時の irAE 再燃/新規発生人数の比較 $\square$ 無症状群, 口 再燃/新規発症群 Fisher の正確確率検定 D : 初回 irAE の Grade の比較 $\square$ 無症状群, 口再燃/新規発症群 Fisher の正確確率検定. 
irAE 発生までの日数が 100 日以内の患者が多かっ た（図 3B）。また，ICIs が再導入された女性で は無症状の患者より, irAEが再燃/新規発生した 患者が多かった（図3C）。一方，その初回発生 時のirAEの Grade は有意なリスク因子ではなかっ た（図3D）.

\section{考察}

Santini らの先行研究では, 非小細胞肺がん患者 に扔いて ICIs 再導入時の安全性を調査し, ICIs 導 入から初回 irAE が生じるまでの日数（3 カ月）は 統計学的に $\operatorname{irAE}$ 再燃/新規発症の有意なりスク因

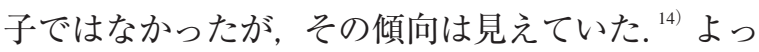
て本研究では, その日数再検討する価值があると 考えた。今回研究対象となった，ニボルマブは 14 日，イピリムマブやペムブロリズマブおよび アテゾリズマブは 21 日間隔で使用する薬剤であ る.よって，なるべく各薬剤の投与間隔日数の倍 数でコース数をカウントできうる近い日数かつ区 切りの良い日数ということで 100 日を設定した. その結果，重篤な irAE で ICIs 投与が休薬となり， 再導入した場合, ICIs 導入から初回 irAE 発生ま での日数 100 日以下であることが，irAE 再燃あ るいは新規発症のリスク因子となる可能性がある ことがわかった。この意義としては, ICIs の適応 が拡大している近年において, 適応臟器横断的か つ使用薬郕横断的な結果が本邦にて得られたこと も大きい，さらに，ICIs が再導入された女性では 無症状の患者より, irAE が再燃 / 新規発生した患 者が多かった，我々の文献調査では，irAEの発症 リスクと性差の一般的な関係の報告はなく，不明 だった。ちなみに既報 ${ }^{14)}$ では，これに関して男女 に有意な差はないという結果である。しかし，女 性のほうが男性よりも ICIs 再導入によって irAE が再燃 / 新規発症しやすい可能性があるというこ とは, 興味樑い結果である。

一方, 表 3 から初回 irAEの Grade やそれに対 するステロイド使用の有無, ICIs の休薬期間と いった, irAE 治療関連事象が, その再燃/新規発 症に影響する可能性は低い。これは既報 ${ }^{14)}$ と一 致している。よって, irAEが発生した際は，後
の治療への影響を考えるよりも第一に, その状況 から患者を回復させるため, ステロイドを含めた 手段を用い，適切な時期に再開を試みることが大 切だろう。

これらリスク因子の検討は, 本研究では単変量 解析を用いて行った. しかし, 単施設での研究で あることから，ICIs の中止および再導入という条 件を満たす症例数の確保に限界があった。 今後, 近隣の施設への呼びかけや，もちろん当院での症 例集積を経て, 患者背景因子の結果への影響を考 慮し，多変量解析を行うことが課題であろう。こ れに関しては続報として取り組む予定である。

また，統計学的には，再導入によって $\operatorname{irAE}$ 再燃あるいは新規発症した場合も, 初回と比べて その Grade は有意に増加せず，マネジメント可能 であることが示唆された。しかし, これは, 再導 入時の患者選択が重要だと考察する. 例えば本研 究で肺臓炎のirAEに注目すると, 非再導入群で 11 例なのに対し, 再導入群では 1 例である. 本研 究ではICIs の再導入の基準は各薬剤の添付文書 および適正使用ガイド, ガイドライン等に基づき, 主治医の判断に委ねられていた。つまり, 初回発 現の irAEが肺臓炎であった場合, そもそも ICIs 再導入自体が当院に拉いて避けられていた傾向が ある。これには， ICIs 自体が有する肺蔵炎発症リ スクの高さ ${ }^{15)}$ や, 再導入時の肺臓炎再発率の高 さ ${ }^{16)}$ が背景にあると推察する. 実際に, Grade 1 にもかかわらず, 再導入群の肺臓炎の患者は, 再 び肺臓炎を発症した。これに対して, 再導入群で は, 甲状腺機能低下症や副腎不全といったホルモ ン補充治療でマネジメント可能な内分泌疾患関連 の irAEが多かった。これら内分泌障害は，ガイ ドライン ${ }^{9)}$ 上も，重篤な Grade が生じても，ホル モン補充にて症状が安定すれば慎重な ICIs 再投 与が許容されている. よって, ICIs 導入によって irAE が再燃あるいは新規発症した場合の安全性 は, 初回に生じた irAEの特性を理解してこそ担 保されると考察する.

本研究のさらなる発展としては, ICIs 再導入群 と非再導入群で予後を調查し, ICIs 再導入の安全 性に加えて治療効果を評価することが有用と考え る. Santini らの先行研究 ${ }^{14)}$ では, ICIs を再導入す 
る直前の Response evaluation criteria in solid tumors v1.1（RECIST v1.1）評価で partial response（PR） あるいは complete response（CR）が得られてい なかった患者のみが ICIs 再導入で全生存期間が 延長したと示されている.さらに， National Comprehensive Cancer Network（NCCN） supportive care ガイドラインでも, ICIs 再導入時は, 必ず病 勢の評価を行うよう推奨されている.これに加え， irAEの出現は治療予後と相関するという報告も ある. ${ }^{3)}$ 再導入群のなかでも，再燃 / 新規発症群と 無症状群で ICIs の治療反応性や治療予後に差が 生じるのかということも今後の研究課題として興 味深く，フォローアップを行う予定である.

以上より，ICIs 再導入に拈ける患者のリスクベ ネフィットをより正確に評価するうえで，本研究 によって ICIs 導入から初回 irAE 発生までの日数 や性別，その特性が重要であることが示唆され， ICIs 再導入群と非再導入群の予後比較調査が今後 必要だと考察する。

\section{利益相反}

開示すべき利益相反はない.

\section{引用文献}

1）門野岳史, 免疫チェックポイント阻害剤におけ る免疫関連副作用の実際, 日本臨床免疫学会会 誌, 2017, 40, 83-89.

2）只野裕己, 鳥越俊彦, 免疫チェックポイント阻害 剂の免疫関連副作用, 日本臨床免疫学会会誌, 2017, 40, 102-108.

3) Postow MA, Sidlow R, Hellmann MD, Immunerelated adverse events associated with immune check point blockade, $N$ Engl J Med, 2018, 378, 158-168.

4) Topalian SL, Hodi FS, Brahmer JR, Gettinger SN, Smith DC, McDemott DF, Powderly JD, Carvajal RD, Sosman JA, Leming PD, Spiqel DR, Antonia SJ, Hom L, Drake CG, Pardoll DM, Chen L, Sharfman WH, Anders RA, Taube JM, McMiller TL, Xu H, Koman JA, Jure-Kunkel M, Aqrawal S, McDonald D, Kollia GD, Gupta A, wigginton JM, Sznol M, Safety, activity, and immune correlates of
anti-PD-1 antibody in cancer, $N$ Engl J Med, 2012, 366, 2443-2454.

5) Hodi FS, O’Day SJ, McDemott DF, Weber RW, Sosman JA, Haanen JB, Gonzalez R, Robert C, Schadendorf D, Hassel JC, Akerley W, van den Eertwegh AJ, Lutzky J, Lorigan P, Vaubel JM, Linette GP, Ottensmeier CH, Lebbe C, Peschel C, Clark JI, Wolchok JD, Weber JS, Tian J, Yellin MJ, Nichol GM, Improved Survival with Ipilimumab in Patients with Metastatic Melanoma, N Engl J Med, 2010, 363, 711-723.

6）山口佳之, 堅田洋祐, 岡脇 誠, 山村真弘, 谷岡 洋亮, 永坂岳司, 免疫チェックポイント阻害剤の 副作用と対策緒言, 癌と化学療法, 2018, 45, 10171020 .

7) Zhou S, Khanal S, Zhang H, Risk of immune-related adverse events associated with ipilimumab-plusnivolumab and nivolumab therapy in cancer patients, Ther Clin Risk Manag, 2019, 15, 11-221. doi: 10.2147/ TCRM. S193338.

8) Fujii T, Colen RR, Bilen MA, Hess KR, Haiiar J, Suarez-Almazor ME, Alshawa A, Hong DS, Tsimberidou A, Janku F, Gong J, Stephen B, Subbiah V, Piha-Paul SA, Fu S, Sharma P, Mendoza T, Patel A, Thirumurthi S, Sheshadri A, Meric-Bemstam F, Naing A, Incidence of immune-related adverse events and its association with treatment outcomes: the MD Anderson Cancer Center experience, Invest New Drugs, 2018, 36, 638-646.

9) Brahmer JR, Lacchetti C, Schneider BJ, Atkins MB, Brassil KJ, Caterino JM, Chau I, Emstoff MS, Gargner JM, Gnex P, Hallmeyer S, Hotter Chakrabarty J, Leighl NB, Mammen JS, McDermott DF, Naing A, Nastoupil LJ, Porter LD, Puzanov I, Reichner CA, Santomasso BD, Seigel C, Spira A, Suarez-Almazor ME, Wang Y, Wolchok JD, Thompson JA, Management of immune-related adverse events in patients treated with immune checkpoint inhibitor: american society of clinical oncology clinical practice guideline, J Clin Oncol, 2018, 36, 1714-1768.

10) Nomura M, Ostuka A, Kondo T, Nagai H, Nomura Y, Kaku Y, Matsumoto S, Muto M, Efficacy and safety of retreatment with nivolumab in metastatic melanoma patients previously treated with nivolumab, Cancer Chemother Pharmacol, 2017, 80, 999-1004.

11) Niki M, Nakaya A, Kurata $T$, Yoshioka H, Kaneda $T$, 
Kibata K, Ogata M, Nomura S, Immune checkpoint inhibitor re-challenge in patients with advanced nonsmall cell lung cancer, Oncotarget, 2018, 9, 3229832304.

12) Fujita K, Uchida N, Kanai O, Okamura M, Nakatani K, Mio T, Retreatment with pembrolizumab in advanced non-small cell lung cancer patients previously treated with nivolumab: emerging reports of 12 cases, Cancer Chemother Pharmacol, 2018, 81, 1105-1109.

13) Hakozaki T, Okuma Y, Kashima J, Re-challenging immune checkpoint inhibitor in a patient with advanced non-small cell lung cancer: a case report, BMC Cancer, 2018, Article number 302. doi: 10. 1186/s12885-018-4212-1.

14) Santini FC, Rizvi H, Plodkowski AJ, Ni A, Lacouture ME, Gambarin-Gelwan M, Wilkins O,
Panora E, Halpenny DF, Long NM, Kris MG, Rudin CM, Chatt JE, Hellmann MD, Safety and efficacy of re-treating with immunotherapy after immunerelated adverse events in patients with NSCLC, Cancer Immunol Res, 2018, 6, 1093-1099.

15) Hu YB, Zhang Q, Li HJ, Michot HB, Liu HB, Zhan P, Lv TF, Song Y, Evaluation of rare but severe immune related adverse effects in PD-1 and PD-L1 inhibitors in non-small cell lung cancer: a metaanalysis, Transl Lung Cancer Res, 2017, 6, S8-S20.

16) Nishino M, Ramaiya NH, Awad MM, Sholl LM, Maattala JA, Taibi M, Hatabu H, Ott PA, Armand PF, Hodi FS, PD-1 inhibitor-related pneumonitis in advanced cancer patients: radiographic patterns and clinical course, Clin Cancer Res, 2016, 22, 60516060 . 